\title{
Corporate Life Cycle and the Explanatory Power of Risk Measures versus Performance Measures
}

\author{
Hamed Omrani ${ }^{1}$, KeramatOllah Heydari Rostami ${ }^{1}$, Saber Samadi ${ }^{1}$, Ahmad Kazemi Margavi ${ }^{1}$, \\ Hamid Asadzadeh ${ }^{1}$, Hemad Nazari² \\ ${ }^{1}$ University of Tehran, Iran \\ 2University of Tehran Azad Oloom VA Tahghighat, Iran \\ *heydarykeramat@gmail.com
}

\begin{abstract}
The major aim of this paper is to compare the explanatory power of risk measures versus performance measures in different life-cycle stages. To test the hypotheses, first, sample firms were classified into three life-cycle stages (Growth, Mature and Decline). Then, using regression models and Vuong's Z-statistic, the hypotheses were investigated. In this study, financial information of 75 firms which were accepted at Tehran's Stock Exchange (TSE) from 2003 to 2008 (450 firm-years) was examined. The results of this study show that in growth and decline stages, the explanatory power of risk measures is significantly higher than performance measures and in mature stage, the opposite is true.
\end{abstract}

Key Words: Corporate Life-Cycle, Risk measures, Performance measures, Explanatory power.

\section{Introduction}

Main objective of financial reporting is to provide relevant and reliable information to interested third parties (Financial Accounting Standards Board, 1978). Financial reports are a means to communicate operating results and financial conditions of the firm to interested parties external to the firm. Users can then utilize this information to evaluate the performance and financial condition of the firm for investment decisions, fiduciary purposes, or other uses. However, not all firms reporting the same operating results and/or financial conditions have the same or similar market values. Other factors are likely to lead market values to differ among firms with similar operating results and financial conditions (Park and Chen, 2006). Prior researches simply those economic characteristics such as corporate life cycle play important roles in firm valuation and value relevance of accounting information (Anthony and Ramesh, 1992; Black, 1998; Jenkins et al., 2004; Xu, 2007). Life cycle theory suggests that a firm possesses different risk characteristics and different attributes economic at different life cycle (Xu, 2007). A number of financial accounting researches have focused on investigation the effect of corporate life cycle stage on the value relevance of financial accounting information.

These researches findings indicate that the reaction and respond of capital markets to accounting information in different stages of the life cycle differ effectively (Anthony and Ramesh, 1992; Sugianis, 1996; Black, 1998; Martinez, 2003; Jenkins et al., 2004; Park and Chen, 2006; Xu, 2007). These researches suggest that performance measures and risk measures playa more important valuation role at a certain life cycle stage than at another life cycle stage. However, whatever has not been examined in any previous studies and is the basis and main assumptions of this research is that in each stages of life cycle (growth, maturity and decline) which of performance and risk criteria has more importance for capital markets and which of these criteria can predict stock returns. Therefore, the major aim of this paper is to compare the explanatory power of risk measures versus performance measures in forecasting stock returns across corporate life cycle stages (growth, maturity, and decline). The paper is organized as follows. In the next session, we review relevant literature and develop our hypothesis. In section 3 , we describe our data, Life cycle partition and research method. The fourth section presents the result of the empirical analysis and finally, we present a discussion of the conclusions that can be derived from the results in the last section.

\section{Literature Review}

Among early studies, Ou and Penman (1989) investigate life cycle effect on the explanatory power of ratios financial in the prediction of stock returns Their findings show that the information content of financial ratios to predict stock returns at different stages of life cycle have different significance to each 
other . After that, Anthony and Ramesh (1992) show that the value relevance of performance measures (such as sales and capital investment growth) are higher at early life cycle stages and are valued higher by capital markets. Sugianis (1996) documents that Explanatory power of R \& D expenditure has the highest value in growth stage and the lowest value in the decline stage. Black (1998) shows that the value relevance of cash flow information (operating, investing and financing information) relative to earnings varies across life cycle stages. Park and Chen (2006) show that the equity market processes accounting information differently for firms at different life-cycle stages. Xu (2007) suggests that the incremental explanatory power of risk factors is more important in the growth and stagnant stages but much less important in the mature stage.

Characteristics of firms in different organizational life cycles stages: Life cycle theory suggests that a firm possesses different risk characteristics and different economic attributes across life cycle stages $\mathrm{Xu}$, 2007). Economic theory divides a corporate life cycle into four stages: start-up, growth, maturity and decline or stagnation stage. These stages are discerned by corporate-specific attributes such as the degree of uncertainty that faces the corporate, its assets in place and its investment opportunities (Mueller, 1972, 1975; Myers, 1977). Growing and aging stages show business units based on the ability to control and flexibility. In young (growing period), business unit is very flexible, but in most cases they are noncontrollable. By increasing business unit's life ages, Relationships changed control increases and flexibility decreases. Finally, aging (the decline period) the ability to control will be decreased. When business unit has the ability to control and is flexible, indicate that has young and aging benefits simultaneously, this situation is known as evolved stage (maturity). Figure (1) is describing the relationship between capability of control and flexibility in commercial units (Adizes, 1989).

\section{Figure 1: The relationship between capability of control and flexibility in commercial units}

Capability of control flexibility

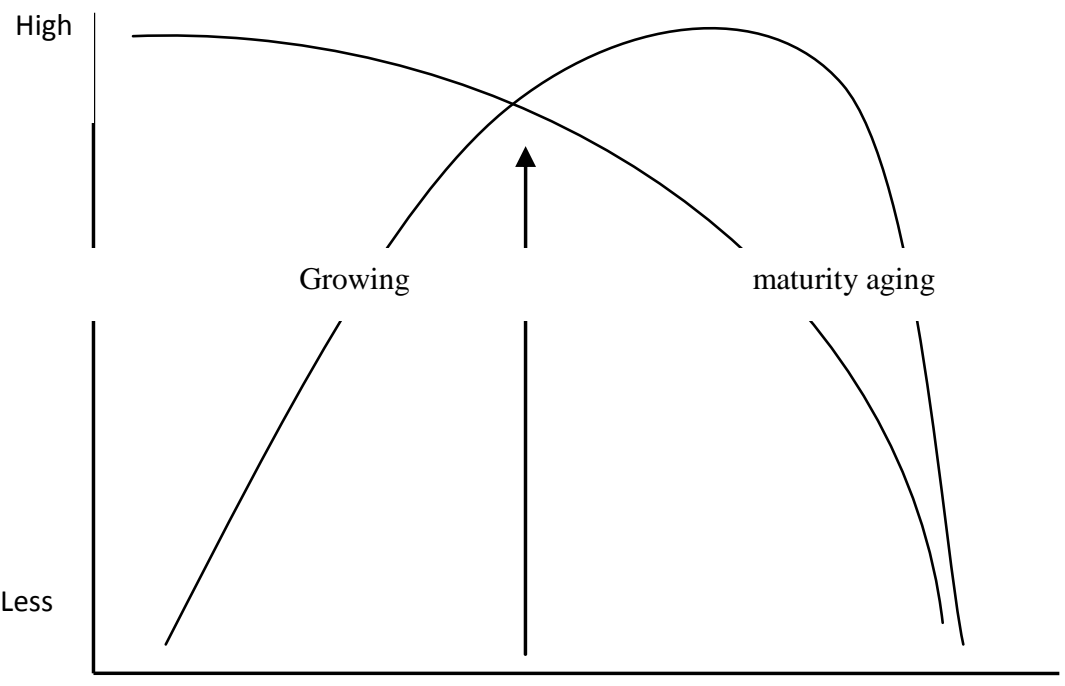

In birth or emergence stage, assets (firm size)is usually located in low amount, operating cash flows and profitability are low and companies need high liquidity to finance and achieve growth opportunities. Dividends ratio is usually zero or a maximum of $10 \%$ in these companies and the investment returns or adjusted investment returns is sometimes negligible compared with common financing rate. Firm size is more than it is in emergence stage and it has excessive rise in the level of sales and earnings growth compared with emergence stage. More financial resources are invested in productive assets and the company has greater flexibility in liquidity indicators. Dividends ratio in this spectrum of companies, is usually between $10 \%$ and $50 \%$ fluctuate.

Investment return or adjusted investment returns is more than funding costs in most cases. In maturity, stage companies experience a stable and balanced sells, and requiring cash is financed through internal resources in most cases. Assets size of these companies also much higher proportion of assets in growth stage companies and dividends ratio in these companies is usually swing between $50 \%$ and $100 \%$. Due to abundant liquidity and reducing reliance of outside financing policies, investment returns or adjusted 
investment returns are equal to or more than the rate of funding generally. Opportunities were very small indeed in Decline or stagnation stage of growth. Profitability indexes, liquidity and playing commitments had a decreasing trend and the company had been in very severe competitive conditions, while the cost of external financing is also high in such a manner that the investment return or adjusted investment return is less than rate of financing in most cases. (Adizes, 1989, Mueller, 1972, 1975; Myers, 1977)

Hypothesis: Corporate life cycle theory assumes that a Corporate will exhibit different attributes in some important aspects at different life cycle stages. Strategic focus and selected performance measures can therefore be different across life cycle stages (Richardson and Gordon, 1980; Rappaport, 1981).Capital markets incorporate information on both benefit and risk underlying an as set into the asset price. Weights place on benefit and risk may vary across different cases or situations. For a certain life cycle stage, if performance is the major concern of capital markets, market returns will concentrate on information contained in performance measures and risk measures may have are latively low incremental explanatory power. In contrast, if risk is the major concern, market returns will concentrate on information contained in risk measures and these measures may have a relatively higher incremental explanatory power $(\mathrm{Xu}, 2007)$. Prior researches suggest that performance measures and risk measures playa more important valuation role at a certain life cycle stage than at another life cyclist age (Anthony and Ramesh, 1992; Sugianis, 1996; Black, 1998; Xu, 2007) .Considering the above and financial aspects of companies at different stages of life cycle (mentioned in Section 2.2) hypothesis of this research is to be mentioned:

$\boldsymbol{H}_{1}$ : In growth stage, descriptive content of the performance and risk Measures have significant differences.

$H_{1:}: R_{P M}^{2} \neq R_{R M}^{2}$

$\boldsymbol{H}_{2}$ : In maturation stage, descriptive content of the performance and risk Measures have significant differences.

$H_{2}: R_{P M}^{2} \neq R_{R M}^{2}$

$\mathbf{H}_{3}$ : In the decline stage, descriptive content of the performance and risk Measures have significant differences.

$H_{3}: R_{P M}^{2} \neq R_{R M}^{2}$

To better compare the explanatory power of risk measures relative to performance measures across life cycle stages, we calculate explanatory power of risk factors $\left(R_{R M}^{2}\right)$ in relation to the explanatory power $\left(\mathrm{R}_{\mathrm{pM}}^{2}\right)$ for each life cycle stage.

\section{Methodology}

Life cycle partition: To classify sample firm-years into life-cycle stages, this study uses the following four classification variables used in prior research on life-cycle (Anthony and Ramesh, 1992; Black, 1998; Park and Chen, 2006; $\mathrm{Xu}, 2007)$ : age of the firm (AGE), percent sales growth (SG), capital expenditure divided by total value of the firm (CE), and annual dividend payout divided by net income (DP). In this study, separating the company into growth, maturity, and decline stages by using four aforementioned variables and according to the methodology of Park and Chen (2006) is as follows:

- The four life-cycle stage descriptors (i.e., AGE, SG, CE, and DP) are calculated for each event year (i.e., relative-year 0 ) for each sample firm-year.

- Industry quintiles are calculated for each of the descriptors for each event year using all the Tehran's Stock Exchange (TSE) firms having the same two-digit SIC code as the target firm.

- The four classification variable observations for each firm-year are assigned to each industry quintile of the same variable and they are given a score as shown in figure (2). In figure (2), the composite score ranges from four to twenty. A low dividend payout could signal either high growth opportunities or liquidity problems. While a decline stage firm with liquidity problems would exhibit a low dividend payout, the firm is unlikely to be in the high quintile on the sales growth or capital expenditures variables. Therefore, if the sum of the scores for AGE, SG and CE is low (i.e., smaller than 7), and score for DP is five (four), then one (two) is assigned as DP score for decline stage firm-years.

- Each sample firm-year is classified into life-cycle stages using the following procedure: 
- A firm-year is classified as growth stage observation if its composite score is between sixteen and twenty.

- A firm-year is classified as armature stage observation if its composite score is between nine and fifteen.

- A firm-year is classified as a DECLINE stage observation if its composite score is between four and eight.

Table 1: Score Assignment to Industry Quintile

\begin{tabular}{|c|c|c|c|c|}
\hline \multirow{2}{*}{$\begin{array}{l}\text { Industry } \\
\text { Quintile }\end{array}$} & \multicolumn{4}{|c|}{ Life-Cycle Descriptors } \\
\hline & AGE & DP & CE & SG \\
\hline $0 \%-20 \%$ & 5 & 1 & 1 & $5(1)^{*}$ \\
\hline $20 \%-40 \%$ & 4 & 2 & 2 & $4(2)^{*}$ \\
\hline $40 \%-60 \%$ & 3 & 3 & 3 & 3 \\
\hline $60 \%-80 \%$ & 2 & 4 & 4 & 3 \\
\hline $80 \%-100 \%$ & 1 & 5 & 5 & 3 \\
\hline
\end{tabular}

Note*: If the sum of scores for AGE, SG, and CE is low (i.e., smaller than 7.5), and DP is at the lowest (second lowest) quintile, then one (two) is assigned as the DP score for decline stage firm-years. Notes*: The table is based on Park and Chen (2006).

Model Specification: Unlike the CAPM model in which risk of a stock is associated with one factor, the APT model, risk is influenced by several factors (Ross, 1976; Roll, 1977). Several empirical researches examine accounting variables to assess their relationship with risk or their ability to predict their risk. Findings of these researches show that stock returns influenced by risk factors such as book-to-market ratio, beta, size and advantage. (Banz, 1981; Keim, 1983; Brown et al., 1983; Baribeau, 1989; Fama and French, 1992; Xu, 2007). Following empirical accounting studies, we incorporate risk measures examined by prior studies under the topic, and specify the following empirical model:

$R_{j \mathrm{t}}=\boldsymbol{\beta}_{1}+\boldsymbol{\beta}_{1} \mathrm{BM}_{\mathrm{jt}}+\boldsymbol{\beta}_{2}$ BETA $_{\mathrm{jt}}+\boldsymbol{\beta}_{\mathbf{3}} \operatorname{SIZE}_{\mathrm{jt}}+\boldsymbol{\beta}_{\mathbf{4}} \mathrm{LEV}_{\mathrm{jt}}+\boldsymbol{\varepsilon}_{\mathrm{jt}}(\mathbf{1})$

where $\mathrm{R}_{\mathrm{jt}}$, natural log of 12 -month cumulative security return measured four months after the fiscal-year end for firm j; $\mathrm{BM}_{\mathrm{j} t}$, natural log of book-to-market ratio for firm j; BETAjt, natural log of beta, measured using the CAPM model for firm $j$; SIZE $\mathbf{j t}_{\mathbf{j t}}$, natural log of beginning market value of equity for firm $\mathbf{j}$; $\mathrm{LEV}_{\mathbf{j t}}$, natural log of long-term debt divided by total assets for firm $\mathrm{j}$;

Based on Clean Surplus Theory (Ohlson, 1995) and (Ohlson and Feltham, 1995) the Company's equity value is equal to book value of equity plus the present value of discounted future abnormal profits. After Ohlson (1995) and Ohlson and Feltham (1995)several researchers investigate accounting variables related to accounting firm performance and the ability of these variables in predicting stock returns. Findings show that stock returns influenced by performance criteria such as returns, earnings, sales, capital expenditure, cash flows from operation (CFO) profitability, etc. (Anthony and Ramesh, 1992; Black, 1998; Martinez, 2003; Xu, 2007 and so on). Following empirical accounting studies, we incorporate risk measures examined by prior studies under the topic, and specify the following empirical model:

$R_{j \mathrm{jt}}=\beta_{0}+\beta_{1} \Delta \mathrm{SG}_{\mathrm{jt}}+\beta_{2} \Delta \mathrm{CE}_{\mathrm{jt}}+\boldsymbol{\beta}_{3} \Delta \mathrm{CFO}_{\mathrm{jt}}+\boldsymbol{\beta}_{4} \Delta \mathrm{ROS}_{\mathrm{jt}}+\boldsymbol{\beta}_{5} \Delta \mathrm{NI} \mathrm{jt}_{\mathrm{jt}}+\boldsymbol{\varepsilon}_{\mathrm{jt}}(2)$

where $\mathrm{R}_{\mathrm{j} \mathrm{t}}$, natural log of 12 -month cumulative security return measured four months after the fiscal-year end for firm $\mathrm{j} \mathrm{SG}_{\mathbf{j} t}$, natural log of change in percentage sales growth for firm $\mathrm{j}$; $\mathrm{CE}_{\mathbf{j}}$, natural $\log$ of differenced capital expenditure divided by prior-year market value for firm $\mathrm{j}$; $\mathrm{CFO}_{\mathbf{j t}}$, natural $\log$ of differenced cash flows from operation divided by prior-year market value for firm $j$; $R 0 S_{j t}$, natural $\log$ of differenced profitability; profitability is measured as earnings before extraordinary items divided by sales for firm $\mathrm{j}$; $\mathrm{NI}_{\mathrm{j}}$, natural log of differenced earnings measured as earnings before extraordinary items divided by prior-year market value for firm j;

Equations (1) and (2) are estimated using the full sample with life cycle dummy variables interacting with each independent variable included. Life cycle dummy variables are defined as:

$G$, dummy variable, one if the firm is at growth stage, zero otherwise;

$M$, dummy variable, one if the firm is at mature stage, zero otherwise;

$S$, dummy variable, one if the firm is at stagnant stage, zero otherwise. 
Then it is calculated adjusted coefficient of determination $\left(\mathrm{R}^{2}\right)$ that shows explanatory power, for each aforementioned model in each stage of growth, maturity and declined. By using statistic test of Z Wong, it is clarified that whether coefficient of determination of two models in each stages have significant differences (Vuong, 1989). If in each stages, statistic of Z Wong shows that coefficient of determination of two models have significant differences, it can be concluded that in that stage, the model that has higher adjusted coefficient of determination has more explanatory power.

Data and Sample: The sample firm-years are selected from firms, which were accepted at Tehran's Stock Exchange (TSE) for the period 2003 through 2008 that satisfy the following sampling criteria:

- It should not be mediated component of investment firms or financial holding, leasing, and bank.

- In order to establish comparability of financial year-end of company is leading to the Persian month Esfand 29th (March 20).

- Company's financial information in the course of study is available.

- Stock trading companies continuously in Tehran Stock Exchange (TSE) and do not have stopped trading over a month.

- $\quad$ According to the above conditions, 75 company (450 years - companies) during 2003 and 2008 were selected and in those 112, 158 and 180 years - companies were in growing, mature and decline stages respectively.

\section{Results}

Descriptive Statistics: Table 2 shows descriptive statistics of explanatory variables and the variables classified as corporate life cycle stages of the growing, maturity and decline separately. As you will see, a wide deviation is observed between descriptive statistics of variables mentioned in the life cycle stages. Sales growth and capital expenditures have declining stream from the growth stage. Companies in growth stage have the highest sales growth, maximum cost and minimum capital ratio of dividends and companies in the decline stage have the lowest sales growth, the lowest cost and highest ratio of capital dividends rate. The maximum size of company owned by companies in maturity stage and minimum size owned by firms in the decline stage. Overall, Table 1 provided our expectations of the financial characteristics of different stages of life cycle based on the figure 1 . The correlation coefficients between the variables are presented in Table (2). As expected returns has an inverse relationship with firm size and CAPM beta coefficient and has a direct relation with operating cash flows, sales growth, capital expenditures, etc.

Table 2: Descriptive Statistics

\begin{tabular}{|c|c|c|c|c|c|c|c|c|c|}
\hline \multirow{2}{*}{ Variables } & & \multicolumn{2}{|c|}{ Full $(n=450)$} & \multicolumn{2}{|c|}{ Growth $(n=112)$} & \multicolumn{2}{|c|}{ Mature(n=158) } & \multicolumn{2}{|c|}{ Stagnant(n=180) } \\
\hline & & Median & $\begin{array}{l}\text { Standard } \\
\text { Deviation }\end{array}$ & Median & $\begin{array}{r}\text { Standard } \\
\text { Deviation }\end{array}$ & Median & $\begin{array}{r}\text { Standard } \\
\text { Deviation }\end{array}$ & Median & $\begin{array}{r}\text { Standard } \\
\text { Deviation }\end{array}$ \\
\hline Dependent & $\mathrm{R}$ & 0.424 & 10.234 & 0.498 & 13.768 & 0.673 & 8.643 & 0.365 & 5.674 \\
\hline \multirow{4}{*}{ 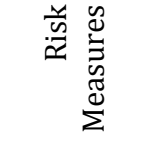 } & $\mathrm{BM}$ & 0.712 & 4.302 & 0.621 & 2.653 & 0.785 & 7.432 & 0.541 & 4.129 \\
\hline & BETA & 0.817 & 4.476 & 1.023 & 6.972 & 0.824 & 4.612 & 1.312 & 1.612 \\
\hline & SIZE & 3.716 & 5.013 & 3.871 & 3.851 & 4.362 & 4.971 & 2.651 & 7.431 \\
\hline & LEV & 0.247 & 8.018 & 0.281 & 12.213 & 0.213 & 5.321 & 0.171 & 9.432 \\
\hline \multirow{5}{*}{ 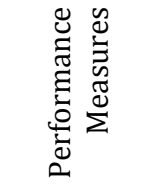 } & $\Delta \mathrm{SG}$ & 0.054 & 5.034 & 0.095 & 3.871 & 0.042 & 5.871 & 0.023 & 4.412 \\
\hline & $\Delta \mathrm{CE}$ & 0.048 & 12.315 & 0.075 & 15.201 & 0.046 & 8.001 & 0.012 & 6.321 \\
\hline & $\Delta \mathrm{CFO}$ & 0.031 & 4.967 & 0.031 & 6.913 & 0.051 & 4.010 & 0.014 & 7.685 \\
\hline & $\triangle \mathrm{ROS}$ & 1.312 & 2.978 & 0.781 & 2.021 & 1.671 & 3.103 & 0.211 & 1.921 \\
\hline & $\Delta \mathrm{NI}$ & 0.281 & 13.614 & 0.231 & 12.731 & 0.318 & 14.801 & 0.074 & 2.901 \\
\hline \multirow{4}{*}{ 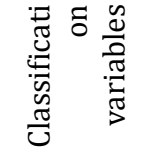 } & SG & 0.485 & 9.678 & 0.653 & 8.434 & 0.387 & 16.786 & 0.091 & 3.897 \\
\hline & DPS & 0.356 & 14.245 & 0.149 & 7.461 & 0.328 & 24.573 & 0.545 & 8.342 \\
\hline & $\mathrm{CE}$ & 0.121 & 11.567 & 0.161 & 13.126 & 0.092 & 13.678 & 0.056 & 6.21 \\
\hline & AGE & 19 & 12.47 & 9 & 10.52 & 17 & 13.84 & 28 & 8.25 \\
\hline
\end{tabular}


Table 3: Variables Pierson coefficient correlation

\begin{tabular}{|c|c|c|c|c|c|c|c|c|c|c|}
\hline & $\mathbf{R}$ & BM & BETA & SIZE & LEV & $\Delta S G$ & $\Delta \mathrm{CE}$ & $\triangle \mathrm{CFO}$ & $\Delta \mathrm{ROS}$ & $\Delta \mathrm{NI}$ \\
\hline $\mathrm{R}$ & 1 & 0.231 & 0.124 & -0.168 & 0.078 & 0.117 & 0.043 & 0.148 & 0.032 & 0.067 \\
\hline $\mathrm{BM}$ & & 1 & -0.051 & -0.101 & 0.021 & -0.064 & -0.032 & -0.094 & -0.003 & -0.062 \\
\hline BETA & & & 1 & -0.010 & 0.018 & 0.024 & -0.053 & 0.156 & 0.002 & -0.047 \\
\hline SIZE & & & & 1 & 0.034 & 0.321 & 0.041 & -0.021 & -0.088 & -0.027 \\
\hline LEV & & & & & 1 & -0.062 & -0.089 & -0.131 & -0.049 & -0.318 \\
\hline$\Delta \mathrm{SG}$ & & & & & & 1 & -0.024 & 0.086 & 0.196 & 0.262 \\
\hline$\Delta \mathrm{CE}$ & & & & & & & 1 & -0.075 & 0.164 & 0.269 \\
\hline$\Delta \mathrm{CFO}$ & & & & & & & & 1 & 0.006 & 0.009 \\
\hline$\triangle \mathrm{ROS}$ & & & & & & & & & 1 & 0.017 \\
\hline$\Delta \mathrm{NI}$ & & & & & & & & & & 1 \\
\hline
\end{tabular}

Hypotheses testing :Results of fitting regression models (1) and (2) for the total sample and statistical samples of each growth, maturity, and decline stage is shown in tables (3) and (4) separately. F statistics showed overall significance of regression. Durbin Watson statistics also indicate lack همخطى between independent variables and independence of residuals. Normality of samples was also approved by the Kolmogorov Smirnov statistics (KS) as well. Tables (3) and (4) are presented the performance criteria explanatory power (RPM2) and risk criteria (RRM2) separately for stages of growing, maturity and decline. As can be seen explanatory power of these criteria vary. Risk criteria explanatory power of the growth, maturity and decline stage equal to $0.241,0.212$ and 0342respectively. Performance criteria explanatory power of the growth, maturity and decline stage equal to $0.181,0.361$ and 0.285 respectively. The statistics Z Wong is used, in order to check whether the explanatory power of risk and performance criteria of the aforementioned stages have a statistically significant difference. (Vuong, 1989). In table (5), the risk and performance Measures explanatory power have been examined by Z Wong statistics in each stages of growth, maturity and decline one by one and make sure they have not been equal. The results show that explanatory power of risk and performance Measures in various stages of the life cycle of the company have significant differences. Risk criteria have more explanatory power for predicting stock returns of performance criteria in stages of growth and decline, and in the stage of maturity, performance criteria have more explanatory power to predict stock returns. Therefore, hypotheses 1 to 3 are confirmed.

Table 4: Life cycle effect on the value relevance of performance measures

\begin{tabular}{|c|c|c|c|c|c|c|c|c|c|c|c|c|c|}
\hline \multicolumn{14}{|c|}{$R_{j t}=\beta 0+\beta_{1} B M_{j t}+\beta_{2}$ BETA $_{j t}+\beta_{3}$ SIZE $_{j t}+\beta_{4} L_{j E}+\varepsilon_{j t}$} \\
\hline \multirow{2}{*}{\multicolumn{2}{|c|}{ Variables }} & \multicolumn{3}{|c|}{ Full(n=450) } & \multicolumn{3}{|c|}{$\operatorname{Growth}(n=112)$} & \multicolumn{3}{|c|}{ Mature(n=158) } & \multicolumn{3}{|c|}{ Stagnant $(n=180)$} \\
\hline & & coef & stat & $\begin{array}{c}P \text { - } \\
\text { value }\end{array}$ & coef & Stat & $\begin{array}{c}\text { P- } \\
\text { value }\end{array}$ & coef & stat & $\begin{array}{c}\text { P- } \\
\text { value }\end{array}$ & coef & stat & $\begin{array}{c}\text { P- } \\
\text { value }\end{array}$ \\
\hline \multirow{4}{*}{ 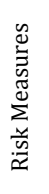 } & BM & $0 / 102$ & $2 / 976$ & $0 / 004$ & $0 / 297$ & $-3 / 861$ & $0 / 00$ & $0 / 145$ & $2 / 976$ & $0 / 004$ & $0 / 112$ & $-2 / 035$ & $0 / 043$ \\
\hline & BETA & $0 / 252$ & $3 / 221$ & $0 / 002$ & $0 / 184$ & $-2 / 707$ & $0 / 009$ & $0 / 451$ & $-3 / 189$ & $0 / 002$ & $0 / 272$ & $1 / 645$ & $0 / 021$ \\
\hline & SIZE & $-0 / 08$ & $4 / 84$ & $0 / 00$ & $-0 / 017$ & $-1 / 992$ & $0 / 05$ & $-0 / 132$ & $2 / 632$ & $0 / 01$ & $-0 / 421$ & $-0 / 573$ & $0 / 568$ \\
\hline & LEV & $0 / 154$ & $1 / 685$ & $0 / 096$ & $0 / 277$ & $-1 / 269$ & $0 / 209$ & $0 / 824$ & $-2 / 235$ & $0 / 029$ & $0 / 191$ & $-2 / 215$ & $0 / 03$ \\
\hline \multicolumn{2}{|c|}{ R2Adjusted } & $0 / 267$ & & & $0 / 241$ & & & $0 / 212$ & & & $0 / 342$ & & \\
\hline \multicolumn{2}{|c|}{$\begin{array}{l}\text { Durbin Watson } \\
\text { statistics }\end{array}$} & $1 / 986$ & & & $2 / 021$ & & & $1 / 911$ & & & $2 / 049$ & & \\
\hline \multicolumn{2}{|c|}{ Statistics F } & $5 / 125$ & & & $8 / 431$ & & & $10 / 151$ & & & $2 / 648$ & & \\
\hline \multicolumn{2}{|c|}{ Statistics KS } & $0 / 213$ & & & $0 / 171$ & & & $0 / 136$ & & & $0 / 267$ & & \\
\hline
\end{tabular}


Table 5: Life cycle effect on the value relevance of risk measures

\begin{tabular}{|c|c|c|c|c|c|c|c|c|c|c|c|c|c|}
\hline \multicolumn{14}{|c|}{$\mathrm{R}_{\mathrm{jt}}=\beta 0+\beta_{1} \Delta \mathrm{SG}_{\mathrm{jt}}+\beta_{2} \Delta \mathrm{CE}_{\mathrm{jt}}+\beta_{3} \Delta \mathrm{CFO}_{\mathrm{jt}}+\beta_{4} \Delta \mathrm{ROS} \mathrm{S}_{\mathrm{jt}}+\beta_{5} \Delta \mathrm{NI} \mathrm{j}_{\mathrm{jt}}+\varepsilon_{\mathrm{jt}}$} \\
\hline \multirow{2}{*}{\multicolumn{2}{|c|}{ Variables }} & \multicolumn{3}{|c|}{ Full(n=450) } & \multicolumn{3}{|c|}{ Growth(n=112) } & \multicolumn{3}{|c|}{ Mature(n=158) } & \multicolumn{3}{|c|}{ Stagnant $(n=180)$} \\
\hline & & coef & stat & $\begin{array}{c}\text { P- } \\
\text { value }\end{array}$ & Coef & stat & $\begin{array}{c}\text { P- } \\
\text { value }\end{array}$ & coef & stat & $\begin{array}{c}\text { P- } \\
\text { value }\end{array}$ & coef & stat & $\begin{array}{c}\text { P- } \\
\text { value }\end{array}$ \\
\hline \multirow{4}{*}{ 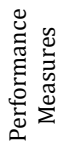 } & $\Delta \mathrm{SG}$ & $0 / 167$ & $2 / 386$ & $0 / 02$ & $0 / 478$ & $-2 / 912$ & $0 / 005$ & $0 / 321$ & $-1 / 995$ & $0 / 05$ & $0 / 271$ & $-3 / 799$ & $0 / 00$ \\
\hline & $\triangle \mathrm{CE}$ & $0 / 121$ & $7 / 663$ & $0 / 00$ & $1 / 254$ & $-2 / 119$ & $0 / 038$ & $1 / 412$ & -1078 & $0 / 285$ & 0511 & $2 / 692$ & $\begin{array}{l}0 / 009 \\
0 / 268\end{array}$ \\
\hline & $\triangle \mathrm{CFO}$ & $0 / 152$ & $-2 / 232$ & $0 / 029$ & $0 / 624$ & $2 / 632$ & $0 / 01$ & $2 / 874$ & $-3 / 189$ & $0 / 002$ & $2 / 706$ & $1 / 109$ & $\begin{array}{l}0 / 268 \\
0 / 038\end{array}$ \\
\hline & $\triangle \mathrm{ROS}$ & $\begin{array}{l}0 / 065 \\
1 / 842\end{array}$ & $\begin{array}{l}1 / 895 \\
-3 / 421\end{array}$ & $\begin{array}{l}0 / 062 \\
0 / 001\end{array}$ & $0 / 102$ & $\begin{array}{l}3 / 654 \\
3 / 009\end{array}$ & $\begin{array}{l}0 / 001 \\
0 / 004\end{array}$ & $\begin{array}{l}0 / 212 \\
5 / 201\end{array}$ & $\begin{array}{l}-1 / 402 \\
-3 / 536\end{array}$ & $\begin{array}{l}0 / 166 \\
0 / 01\end{array}$ & $\begin{array}{l}0 / 082 \\
7 / 112\end{array}$ & $\begin{array}{l}-2 / 119 \\
2 / 632\end{array}$ & $\begin{array}{l}0 / 038 \\
0 / 01\end{array}$ \\
\hline \multirow{2}{*}{\multicolumn{2}{|c|}{$\begin{array}{l}\text { R2Adjusted } \\
\text { Durbin Watson } \\
\text { statistics }\end{array}$}} & $\begin{array}{l}1 / 842 \\
0 / 225\end{array}$ & $-3 / 421$ & & $0 / 183$ & & & $0 / 361$ & & & $0 / 285$ & & \\
\hline & & $1 / 784$ & & & $2 / 053$ & & & $2 / 066$ & & & $1 / 937$ & & \\
\hline \multicolumn{2}{|c|}{ Statistics F } & $3 / 289$ & & & $4 / 702$ & & & $2 / 648$ & & & $7 / 661$ & & \\
\hline \multicolumn{2}{|c|}{ Statistics KS } & $0 / 565$ & & & $0 / 304$ & & & $0 / 797$ & & & $0 / 615$ & & \\
\hline
\end{tabular}

Table 6: Explanatory power of risk measures versus performance measures across life cycle stages

\begin{tabular}{|c|c|c|c|}
\hline Explanatory power & Growth & Maturity & Decline \\
\hline Risk measures $\left(\mathbb{R}_{\mathrm{R} N \mathrm{I}}^{2}\right)$ & $0 / 241$ & $0 / 212$ & $0 / 342$ \\
\hline Performance measures $\left(\mathbb{R}_{\mathbb{P M}}^{2}\right)$ & $0 / 183$ & $0 / 361$ & $0 / 282$ \\
\hline $\mathrm{R}_{\mathrm{RNO}}^{2} / \mathrm{R}_{\mathrm{PMI}}^{2}$ & $1 / 317$ & $0 / 671$ & $1 / 213$ \\
\hline Vuong's Z-statistic & $(1 / 743)^{*}$ & $(-2 / 103)^{* *}$ & $(-2 / 178)^{* *}$ \\
\hline Results & $\begin{array}{l}\text { First hypothesis } \\
\text { confirmation }\end{array}$ & $\begin{array}{l}\text { Second } \\
\text { hypothesis } \\
\text { confirmation }\end{array}$ & $\begin{array}{l}\text { Third hypothesis } \\
\text { confirmation }\end{array}$ \\
\hline
\end{tabular}

${ }^{*} p<0 / 05 ; * * p<0 / 01$ significance levels (two tailed tests).

\section{Discussion and Conclusion}

According to the theory of life cycle, financial characteristics of a company affected by the stage of the life cycle that company is located in it. In fact, companies are following specific policy by considering each stage of its economic life cycle. These policies are reflected in the company's accounting information. The results of this study show that the explanatory power of risk and performance Measures have significant difference by each other in various stages of the life cycle. As Figure (3) shows the stages of growth and decline, explanatory power of risk Measures is more than performance Measures and in the mature stage, performance criteria have more explanatory power. Companies in the growth stage, investments amount is high in capital projects, there is high ambiguity and uncertainty for net future cash flows of these projects and the future performance of the companies, so it is expected that investment makers have more emphasis on risk factors. Shi (2003) documents that creditors place a higher weight on risk than on benefit when valuing an uncertain R\&D So logically expected that in growth stage, explanatory power of the risk Measures (0.241) is more than performance criteria (0.183) (the first assumption results). Companies that are in maturity stage due to having relatively high share of product markets and sustainable competitive advantages, have stable income and there is less ambiguity and uncertainty about net future cash flows and future performance of the company, it is expected that capital investors have greater emphasis on performance criteria. Therefore logically expected that in mature stage, explanatory power of the performance criteria (0.361) is more than risk criteria $(0.212)$ (the second hypothesis results). Companies in declined stage due to lower market share and product sales; reduced profitability indicators; decrease ability and financial flexibility and particularly because of liquidity problems they are at the border of bankruptcy, and there is high ambiguity and uncertainty for continues of the company's future activities and performance, so investment makers are expected have more emphasis on risk factors.

Therefore it is expected that in the decline stage, explanatory of the risk Measures (0.342) is more than performance criteria (0.285) (the third hypothesis results). Generally, the results of this research are consistent with findings of $\mathrm{Xu}$ (2007). Finally, it is recommended to all capital market participants, decision makers, financial analysts and potential investors that have appropriate plentiful care to the life cycle of the company in analysis of investment projects in financial assets and securities for assessing risks, timing and estimating future net cash flows of their investments according to their different and 
vulnerability to the degree of heterogeneous levels of risk reception, because considering these important factors will be leading to optimal portfolio selection with minimum risk and maximum efficiency. In addition, results of this research have connotations for information production and communications of corporate managers. For example, when performance masseurs are highly priced, managers should consider how to help users had better interpret performance masseurs by using disclosure mechanism. This issue is especially important in conditions where firms are set to issue new shares.

\section{References}

Adizes, I. (1989). Corporate life cycle: How and why corporations grow and Die and what do about it, Englewood Cliffs, NJ.

Anthony, J. H. \& Ramesh, K. (1992). Association between accounting performance measures and stock prices a test of the life cycle hypothesis. Journal of Accounting and Economics, 15, 203-227.

Banz, R. W. (1981). The relationship between return and market value of common stocks. Journal of Financial Economics, 9, 3-18.

Baribeau, M. B. (1989). Leverage risk in the nonfinancial corporate sector. Business Economics, 24, 34-39.

Black, E. L. (1998). Life cycle affects the incremental value-relevance of earnings and cash flow measures. Journal of Financial Statement Analysis, 4(1), 40-56.

Brown, P., Kleidon, A. \& Marsh, T. (1983). New evidence on the nature of size-related anomalies in stock prices. Journal of Financial Economics, 12, 33-56.

Fama, F. \& French, K. (1992). The cross sections of expected stock returns. Journal of Finance, 47(2), 42765.

Feltham, G. \& Ohlson, J. (1995). Valuation and Clean Surplus Accounting for Operating and Financial Activities. Contemporary Accounting Research, 689-731.

Financial Accounting Standards Board. (1978). Statement of Financial Accounting Concepts No. 1: Objectives of Financial Reporting by Business Enterprises, Stamford, CT.

Jenkins, D. S., Kane, G. D. \& Velury, U. (2004). The impact of the corporate life cycle on the value-relevance of disaggregated earnings components. Review of Accounting and Finance, 3, 5-20.

Keim, D. (1983). Size-related anomalies and stock return seasonality: empirical evidence. Journal of Financial Economics, 12, 13-32.

Martinez, I. (2003). The impact of firm specific attributes on the value relevance in earnings and cash flows: a nonlinear relationship between stock returns and accounting numbers. Review of Accounting and Finance, 2, 16-39.

Mueller, D. C. (1972). A Life Cycle Theory of the Firm. Journal of Industrial Economics, 20(3), 199-219.

Mueller, D. C. (1975). Life Cycle Effects on Corporate Returns on Retentions. There view of Economics and Statistics, 57(4), 400-409.

Myers, S. C. (1977). Determinants of Corporate Borrowing. Journal of Financial Economics, 5, 147-175.

Ohlson, J. (1995). Earnings, book values, and dividends in security valuation. Contemporary Accounting Research, 11, 661-87.

Ou, J. \& Penman, S. (1989). Financial Statement Analysis and the Prediction of Return. Journal of Accounting \& Economics, 11, $299-305$.

Park, Y. \& Chen, K. (2006). The Effect of Accounting Conservatism and Life-Cycle Stages on Firm Valuation. Journal of Applied Business Research, 22, 75-92.

Rappaport, A. (1981). Selecting strategies that create shareholder value. Harvard Business Review, MayJune, 139-49.

Richardson, R. P. \& Gordon, J. R. (1980). Measuring total manufacturing performance, Sloan Management Review, 47-58.

Roll, R. (1977). A critique of the asset pricing theory's tests; part I: on past and potential testability of testability of theory. Journal of Financial Economics, 4, 129-76.

Ross, S. A. (1976). The arbitrage theory of asset pricing. Journal of Economic Theory, 13, 341-60.

Shi, C. (2003). On the trade-off between the future benefits and riskiness of R\&D: a bondholders' perspective. Journal of Accounting and Economics, 35, 227-54.

Sugianis, T. (1996). The value Relevancy of Research Development on valuation of future Earnings. Journal of Accounting and Economics, 21, 128-142-54.

Vuong, Q. (1989). Likelihood Ratio Test for Model Selection and Non-Nested Hypothesis. Econometrica, 57, 307-333.

$\mathrm{Xu}, \mathrm{B}$. (2007). Life cycle effect on the value Relevance of common risk factor. Review of Accounting and Finance, 6, 162-175. 